\title{
COPERNICUS AND HIS ISLAMIC PREDECESSORS: SOME HISTORICAL REMARKS
}

\author{
F. Jamil Ragep \\ McGill University
}

As a result of research over the past half century, there has been a growing recognition that a number of mathematical models used by Copernicus had originally been developed by Islamic astronomers. This has led to speculation about how Copernicus may have learned of these models and the role they played in the development of his revolutionary, heliocentric cosmology. Most discussion of this connection has thus far been confined to fairly technical issues related to these models; recently, however, it has been argued that the connections may go deeper, extending into the physics of a moving Earth and the way in which astronomy itself was conceived. The purpose of this article is to give an overview of these possible connections between Copernicus and his Islamic predecessors and to discuss some of their implications for Copernican studies.

\section{THE MATHEMATICAL BACKGROUND}

That Copernicus was acquainted with a number of his Islamic predecessors has been evident since 1543, when Copernicus in De revolutionibus explicitly cited five Islamic authors. ${ }^{1}$ The latest of these authors, al-Bițrujjī, flourished in Spain in the last part of the twelfth century, so Copernicus's references end around 1200, which is the approximate terminus date for Islamic authors who were translated into Latin. Until recently, most historiography related to Copernicus has assumed that this was the end of the story, at least as far as Islamic influence goes. But since the 1950s, a series of discoveries has shaken this neatly constricted picture and caused a major re-evaluation of the relation of Copernicus (as well as other Renaissance astronomers) to later Islamic astronomy.

The first modern acknowledgement of a connection between Copernicus and a later (i.e. post-1200) Islamic astronomer was made by J. L. E. Dreyer in 1906. In a footnote, Dreyer noted that the new device invented by Nașīr al-Dīn al-Ṭūsì (d. 1274) was also used by Copernicus in Book III, chap. 4 of De revolutionibus. ${ }^{2}$ Typical for the time, Dreyer offered no further explanation or speculation; nor did anyone else until the discovery in the 1950s of a connection between another Islamic astronomer and Copernicus. E. S. Kennedy, who was a professor of mathematics at the American University of Beirut, happened by chance to notice some unusual (i.e. non-Ptolemaic) astronomical models while browsing through the Nihāyat al$s \bar{u} l$ of 'Alā' al-Dīn Ibn al-Shātịi, a Damascene astronomer of the fourteenth century who had been the time-keeper of the Umayyad Mosque. Upon showing these to his 
friend and mentor, Otto Neugebauer of Brown University, Kennedy was amazed to learn that these models were ones that had been thought to have first appeared in the works of Nicholas Copernicus. This led to a series of articles by Kennedy and his students that discussed various aspects of these models by Ibn al-Shātị as well as by other late Islamic astronomers. ${ }^{3}$

The picture that emerged can be summarized as follows. Islamic authors from an early period were critical of Ptolemy's methods, observations, and models. ${ }^{4}$ One particular irritant was the use of devices by Ptolemy that violated the accepted physical principles that had been adopted by most astronomers in the ancient and medieval periods. Later Islamic astronomers came to list sixteen of these violations: six having to do with having the reference point for uniform motion of an orb being different from the actual centre of the orb (often referred to as the "equant" problem); nine having to do with a variety of Ptolemaic devices meant to bring about latitudinal variation in the planets' motions (i.e. deviation north or south of the ecliptic); and, finally, an irregular oscillation of the lunar epicycle due to the reference diameter being directed to a "prosneusis" point rather than the deferent centre of the epicycle. ${ }^{5}$ The earliest systematic attempt in Islam to criticize Ptolemy's methods and devices occurred in al-Shukūk calā Bațlamyūs (Doubts against Ptolemy) by Ibn al-Haytham (d. c. 1040), who was better known in Europe for his great work on optics. In addition to his blistering critique of Ptolemy, Ibn al-Haytham also wrote a treatise in which he attempted to deal with some of the problems of Ptolemy's planetary latitude models. ${ }^{6}$ A contemporary of Ibn al-Haytham, Abū 'Ubayd al-Jūzjānī, who was an associate of Abū ${ }^{c}$ Alī Ibn Sīnā (= Avicenna, d. 1037), also dealt with these issues and proposed a model to deal with the equant problem. ${ }^{7}$

These early attempts notwithstanding, the major thrust to provide alternative models occurred in the twelfth century and continued for several centuries thereafter. In Islamic Spain, there were a number of criticisms that questioned the very basis of Ptolemaic astronomy, in particular its use of eccentrics and epicycles, which culminated in an alternative cosmological system by al-Bițūjī that used only orbs that were homocentric with the Earth. ${ }^{8}$ But though Bitrūjī’s work had important influences in Europe - indeed Copernicus mentions his view that Venus is above the $\operatorname{Sun}^{9}$ - the Spanish "revolt" against Ptolemy should be seen as episodic rather than marking the beginning of a long-lived tradition of Islamic homocentric astronomy.

In the Islamic East the situation was otherwise. Beginning in the first half of the thirteenth century, a number of works appeared that proposed alternatives to Ptolemy's planetary models. This was the start of an extremely fruitful period in the history of science in Islam in which a series of creative mathematical models were produced that dealt with the problems of Ptolemaic astronomy. Among the most important of these new models were those of Nașīr al-Dīn al-Ṭūsī (1201-74), Mu'ayyad al-Dīn al-'Urḍī (d. c. 1266), Quṭb al-Dīn al-Shīrāzī (1236-1311), 'Alā' al-Dīn Ibn al-Shātị (d. c. 1375), and Shams al-Dīn al-Khafrī (fl. 1525). ${ }^{10}$ In essence, these astronomers developed mathematical tools (such as the "Ṭūsī couple" and the "Urội lemma") that allowed connected circular motions to reproduce approximately the effects 
brought about by devices such as Ptolemy's equant. ${ }^{11}$ In the case of the rectilinear Țūsì couple, two spheres, one half the size and internally tangent to the other, rotate in opposite directions with the smaller twice as fast as the larger. The result of these motions is that a given point on a diameter of the larger sphere will oscillate rectilinearly. (There is an analogous curvilinear Țūsī couple in which the oscillation is meant to occur on a great circle arc on the surface of a sphere.) What this allowed Ṭūsī and his successors to do was to isolate the aspect of Ptolemy's equant model that brought about a variation in distance between the epicycle centre and the Earth's centre from the aspect that resulted in a variation in speed of the epicycle centre about the Earth. Such mathematical dexterity allowed these astronomers to present models that to a great extent restored uniform circular motion to the heavens while at the same time producing motions of the planets that were almost equivalent to those of Ptolemy. ${ }^{12}$

\section{THE CONNECTION TO COPERNICUS}

Noel Swerdlow and Otto Neugebauer, in discussing this Islamic tradition, famously asked: "What does all this have to do with Copernicus?" Their answer was: "Rather a lot." "In his commentary on Copernicus's Commentariolus, Swerdlow made the case for this connection through a remarkable reconstruction of how Copernicus had arrived at the heliocentric system. According to Swerdlow, Copernicus, somehow aware of this Islamic tradition of non-Ptolemaic astronomy, began his work to reform astronomy under its influence. In particular Copernicus objected explicitly to Ptolemy's use of the equant, an objection that had been a staple of Islamic astronomy for some five centuries at that point (but which seems not to have been made by earlier European astronomers). ${ }^{14}$ Swerdlow then proposed that although Copernicus was able to use some of these models, in particular those of Ibn al-Shātir, to deal with the irregular motion brought about by the first anomaly (the motion of the epicycle centre on the deferent), it was the second anomaly (related to the motion of the planet on the epicycle) that remained problematic. For the outer planets this motion corresponds to the motion of the Earth around the Sun, so a transformation of this motion from an epicyclic to an eccentric would lead to a quasi-heliocentric system, whereby the planet goes around the Sun. Of course the Earth could still remain at rest while the Sun, with the planets going around it, could then go around the Earth. In other words, Copernicus's transformations could have led to a Tychonic system. Swerdlow argued that this was not an option for Copernicus, since it led to the notorious intersection of the spheres of the Sun and Mars, which simply was not possible in the solid-sphere astronomy to which Copernicus was committed. Thus Copernicus was compelled to opt for a heliocentric system with the Earth, as a planet, in motion around the Sun. ${ }^{15}$

In his reconstruction, Swerdlow assumed that Copernicus must have had access to the models of his Islamic predecessors. Because of the scarcity of concrete evidence for this assertion (i.e. translated texts in Latin, earlier European references to these models, or the like), Swerdlow was clearly swayed by the similarity of complex 
geometrical models; independent discovery was simply not an option. As he stated with Neugebauer in 1984:

The planetary models for longitude in the Commentariolus are all based upon the models of Ibn ash-Shātir — although the arrangement for the inferior planets is incorrect - while those for the superior planets in De revolutionibus use the same arrangement as 'Urdī's (sic) and Shīrāzī's model, and for the inferior planets the smaller epicycle is converted into an equivalent rotating eccentricity that constitutes a correct adaptation of Ibn ash-Shātir's model. In both the Commentariolus and De revolutionibus the lunar model is identical to Ibn ash-Shātịr's and finally in both works Copernicus makes it clear that he was addressing the same physical problems of Ptolemy's models as his predecessors. It is obvious that with regard to these problems, his solutions were the same.

The question therefore is not whether, but when, where, and in what form he learned of Marāgha theory. ${ }^{16}$

This has recently been reinforced by Swerdlow:

How Copernicus learned of the models of his [Arabic] predecessors is not known - a transmission through Italy is the most likely path — but the relation between the models is so close that independent invention by Copernicus is all but impossible. ${ }^{17}$

Neugebauer and Swerdlow did have one bit of evidence that seemed to show a likely means of transmission between the Islamic world and Italy. This was a text contained in MS Vat. Gr. 211, in which one finds the Țūsī couple (rectilinear version) and Țūsì's lunar model. Apparently dating from about 1300, it is either a Greek translation or reworking of an Arabic treatise, made perhaps by the Byzantine scholar Gregory Chioniades. ${ }^{18}$ The fact that this manuscript found its way to the Vatican, perhaps in the fifteenth century, provides a possible means for the transmission of knowledge of Țūsì's models. It is also noteworthy that Țūsì's models seem to have been widely known by contemporaries of Copernicus; examples include Giovanni Battista Amico and Girolamo Fracastoro. ${ }^{19}$

The historian of astronomy Willy Hartner also pointed to evidence for transmission from Islamic astronomers to Copernicus. Though he states that independent discovery of these models and devices by Copernicus was "possible", "it seems more probable that the news of his Islamic predecessor's model reached him in some way or other". Here Hartner was speaking of the model of Ibn al-Shātir; he was more certain that another example "proves clearly" the borrowing by Copernicus of the Țūsī couple inasmuch as the lettering in Copernicus's diagram in De revolutionibus follows the standard Arabic lettering rather than what one might expect in Latin. ${ }^{20}$

\section{HISTORIOGRAPHICAL REACTIONS}

One would have expected that these historical discoveries, some of which are now a half-century old, would have caused a substantial reevaluation of the origins of the 
"scientific revolution" or at the least an attempt to deal with the role of Islamic science in that revolution. The fact that this has not yet occurred to any significant degree may be traced to several factors. First, recent trends in the historiography of science have resulted in critiques of the very notion of a "scientific revolution", which have tended to downplay the traditional preeminence of the Copernicus-Galileo-Newton narrative. ${ }^{21}$ But even those who still hold to some notion of a scientific revolution have tended to focus their attention on local contexts (usually European) for explanations and to look at the consequences rather than the origins of Copernicanism. ${ }^{22}$ Second, the increasing realization that Copernicus was rather conservative in his scientific outlook, holding on, for example, to the traditional orbs and their uniform, circular motions, has called his revolutionary status into question. So there seems to be an underlying assumption that the enormous complexity in De revolutionibus is more or less irrelevant for the truly important innovation, heliocentricism, which, according to this view, is all that really mattered for Kepler, Galileo, et al. ${ }^{23}$ Thus the convoluted story of "Copernicus and the Arabs", which is mostly about the complicated but supposedly irrelevant models, becomes more trouble than it is worth. ${ }^{24}$ Third, despite, but in part due to, the trend towards "political correctness", there has been a tendency to essentialize different scientific traditions, sometimes because of a benign cultural relativism, sometimes for more invidious reasons. Thus the "essential" part of the scientific revolution, of which the de-centring of the Earth is fundamental, is seen as European. ${ }^{25}$ Finally, the simple fact of academic boundaries has played a role. Because historians of science specializing in Islamic civilization have tended to be marginalized, in part for disciplinary reasons, in part because of the arcane nature of many of their publications, it has been surprisingly difficult to initiate an on-going dialogue between medieval Latinists, Islamists, and early modernists. ${ }^{26}$

Although the larger history of science community seems so far to have resisted dealing with the implications of the Islamic connection to Copernicus, some historians of astronomy who do not specialize in Islamic science have been influenced by the discoveries of Kennedy and his colleagues. We have already discussed Neugebauer and Swerdlow. Jerzy Dobrzycki and Richard L. Kremer also explored possible connections between Islamic astronomy and early modern European astronomy in their incisive article "Peurbach and Marāgha astronomy"; they raised the distinct possibility that Peurbach may well have developed non-Ptolemaic models based upon Islamic sources that were similar (if not the same) as ones that would be used in the next generation by Copernicus. Given this earlier possibility of transmission, they came to an interesting conclusion: "We may be looking for a means of transmission both more fragmentary and widespread than a single treatise, and at least one of the Marāgha sources must have been available to the Latin West before 1461, the year of Peurbach's death." 27 But not all historians of early modern astronomy have been so willing to accept a connection, even in the face of numerous coincidences. I. N. Veselovsky claimed that it is more likely that Copernicus got the Tūsī couple from a mathematically-related theorem in Proclus's Commentary on the First Book of Euclid's Elements. ${ }^{28}$ More recently, Mario di Bono has maintained that independent 
rediscovery of the Islamic astronomical models by Copernicus and his contemporaries is at least as plausible as intercultural transmission. Somewhat surprisingly, he uses the number of similarities between Islamic and Copernican astronomy as evidence against transmission: "[If] derivation of Copernicus's models from Arab sources ... is the case, it becomes very difficult to explain how such a quantity of models and information, which Copernicus would derive from Arab sources, has left no trace - apart from Țüsì's device - in the works of the other Western astronomers of the time." 29

\section{THE CONCEPTUAL BACKGROUND TO THE COPERNICAN REVOLUTION}

Di Bono's article serves to highlight what has been missing in the analysis of the connection between Islamic astronomy and Copernicus. The emphasis on the models alone obscures several crucial historiographical, conceptual, and physical issues that need to be considered when dealing with the Copernican transformations. Let us first look briefly at some of these historiographical issues. What seems to be overlooked by those who advocate a reinvention by Copernicus and/or his contemporaries of the mathematical models previously used by Islamic astronomers is the lack of an historical context for those models within European astronomy. At the least, one would expect to find some tradition of criticism of Ptolemy in Europe in which those models would make sense. But in fact this is not the case. Copernicus's statement of his dissatisfaction with Ptolemaic astronomy, which is the ostensible reason he gives for his drastic cosmological change, had no precedent in Europe but did have a continuous five-hundred-year precedent in the Islamic world. Here is what he says in the introduction to the Commentariolus:

... these theories [put forth by Ptolemy and most others] were inadequate unless they also envisioned certain equant circles, on account of which it appeared that the planet never moves with uniform velocity either in its deferent sphere or with respect to its proper centre. Therefore a theory of this kind seemed neither perfect enough nor sufficiently in accordance with reason.

Therefore, when I noticed these [difficulties], I often pondered whether perhaps a more reasonable model composed of circles could be found from which every apparent irregularity would follow while everything in itself moved uniformly, just as the principle of perfect motion requires. ${ }^{30}$

Since the Commentariolus is the initial work in which Copernicus presents his new cosmology, one would assume that it would be here, and not in the much later De revolutionibus, in which we should search for his original motivations. ${ }^{31}$ What do we learn from this passage? Copernicus puts himself squarely within the tradition of Islamic criticisms of Ptolemy's violations of uniform, circular motions in the heavens. It is important to keep in mind that this tradition began in the Islamic world as early as the eleventh century and led to the series of alternative models outlined above. Furthermore this tradition lasted for some six centuries in which there was a very 
vigorous discourse that led to various proposals, criticisms, and counter-proposals by an active group of astronomers from many regions of the Islamic world. Those who advocate parallel development would thus seem to be claiming that a centurieslong tradition with no analogue whatsoever in Europe was recapitulated, somehow, in the life of one individual who not only paralleled the criticisms but also the same models and revised models in the course of some thirty years. Needless to say, such an approach is ahistorical in the extreme.

Another point needs to be made here. Di Bono and others have pointed to the Paduan astronomers as a possible source for Copernicus's inspiration. But an important distinction needs to be made. The "return" to homocentric astronomy that was evidently advocated by the Paduans has its parallel and inspiration in the "Andalusian revolt" against Ptolemy in twelfth-century Spain. But this revolt, fomented by such figures as Ibn Bājja, Ibn Țufayl, Ibn Rushd (Averroes), and most importantly by alBițuijīi, who advanced an alternative astronomical/cosmological system, needs to be clearly differentiated from the type of Islamic astronomy that most closely resembles that of Copernicus, i.e. the Eastern hay'a tradition of Ibn al-Haytham, Țūsī, 'Urḍī, Shīrāzī, Ibn al-Shātiri and others. ${ }^{32}$ What we know from the Andalusian revolt is that its extreme position against Ptolemy's epicycles and eccentrics led to a failed project that had virtually no impact on the Eastern hay'a tradition. It would seem odd indeed that this Andalusian tradition, in the guise of Paduan astronomy, would have been a source for Copernicus's alternative models in which epicycles and eccentrics play such a prominent role. It is also important to note that neither among the Paduans nor among European astronomers and natural philosophers before Copernicus is there a criticism of the equant or other Ptolemaic devices that lead to a violation of uniform, circular motion. ${ }^{33}$ One must be careful to distinguish a general criticism of Ptolemy's eccentrics and epicycles (and an advocacy of homocentric astronomy) from the tradition of criticism of Ptolemy's irregular motions that was initiated by Ibn al-Haytham, a tradition that clearly includes Copernicus.

Let us now turn to the conceptual issues involved with the Copernican revolution. In the traditional Aristotelian hierarchy of the sciences, the mathematical sciences (including astronomy) were dependent (or subalternate) to physics/natural philosophy, which itself was subordinate to metaphysics. Obviously in order to overturn the Aristotelian doctrine of a stationary Earth, a doctrine for Aristotelians firmly based upon both natural philosophical and metaphysical principles, Copernicus would have had to conceive of a different type of physics. This physics would need to be, somehow, formulated within the discipline of astronomy itself and somehow independent of Aristotelian natural philosophy. Luckily, he had a number of important precedents for this position.

The most authoritative of these precedents was Ptolemy himself. In the introduction to the Almagest, Ptolemy reverses the order of the sciences and places mathematics above natural philosophy and metaphysics (or "theology"), both of which, he claims, "should rather be called guesswork than knowledge". He goes on to say "that only mathematics can provide sure and unshakeable knowledge to its devotees, provided 
one approaches it rigorously" ${ }^{34}$ Though his position had the potential to free the astronomer from the natural philosopher, in actuality a kind of compromise emerged in which the astronomer and the natural philosopher were said to differ not on the actual set of doctrines but rather on the way to prove them. This is clearly laid out in a passage from Geminus preserved in Simplicius's commentary on Aristotle's physics:

Now in many cases the astronomer and the physicist will propose to prove the same point, e.g., that the Sun is of great size or that the Earth is spherical, but they will not proceed by the same road. The physicist will prove each fact by considerations of essence or substance, of force, of its being better that things should be as they are, or of coming into being and change; the astronomer will prove them by the properties of figures or magnitudes, or by the amount of movement and the time that is appropriate to it. ${ }^{35}$

Most Islamic astronomers followed this formulation, elaborating and clarifying it using the fact/reasoned fact (quia/propter quid) distinction of Aristotle's Posterior analytics. Thus the astronomers were seen as giving the facts of various cosmological issues (e.g. that the Earth was spherical) using observational and mathematical tools as is done in Ptolemy's Almagest, whereas the proof of the natural philosopher, such as in Aristotle's De caelo, provided the reason or the "why" behind these facts. ${ }^{36}$

This relatively benign view of the relationship between the astronomer and the physicist came, over time, to be modified in significant ways. Most likely under the influence of Islamic theologians, who were fundamentally opposed to Aristotelian notions of natural cause, we can see subtle shifts in how physical principles were presented in the introductory parts of astronomical texts. ${ }^{37}$ Nașì al-Dīn al-Ṭūsī, for example, presented the critical principle of the uniformity of celestial motion in such a way that it did not depend upon the ultimate cause. Thus the monoformity of falling bodies, and the uniformity of celestial motions, both of which moved "in a single way", was what was important. It became irrelevant that the former was brought about by a "nature" while the latter was brought about by a "soul". 38

Slowly, then, we see an attempt in Islamic astronomy to provide a self-contained mathematical methodology that ran parallel to the methods of the natural philosophers. But Țūsī for one did not believe that this meant that the astronomer could be completely independent of the natural philosophers and metaphysicians, since there were certain principles that only the natural philosophers could provide the astronomer. In fact this was generally the position of Islamic astronomers with the notable exception of ${ }^{\mathrm{c}} \mathrm{Al} \overline{\mathrm{i}} \mathrm{Q} u \mathrm{sh} \mathrm{j} \overline{\text { in }}$ the fifteenth century.

Qūshjī was the son of the falconer of Ulugh Beg (1394-1449), the Timurid prince who was a generous patron of the sciences and arts. Ulugh Beg was an active supporter and participant in the magnificent Samarqand observatory, which was one of the greatest scientific institutions that had been established up to that time. As a boy, Qūshjī became his protégé and student and eventually occupied an important position at the observatory. After the assassination of Ulugh Beg, Qūshjī was attached to 
various courts in Iran but would end his career in Constantinople under the patronage of Mehmet II, who had conquered the city for the Ottomans.

Qūshjī held that the astronomer had no need for Aristotelian physics and in fact should establish his own physical principles independently of the natural philosophers. ${ }^{39}$ This position had profound implications for one principle in particular, namely that the element earth had a principle of rectilinear inclination that precluded it from moving naturally with a circular motion. ${ }^{40}$ Ṭūsī had maintained that there was no way for the astronomer, using mathematics and observation, to arrive at the "proof of the fact" that the Earth was either moving or at rest. This was contrary to Ptolemy's position in the Almagest (I.7), namely that one could establish a static Earth through observation. After Țūsī, we can trace a three-century discussion in which various authors argued whether he or Ptolemy was correct regarding the possibility of an observational proof of the Earth's state of rest. Qūshjī, though, took a somewhat different approach. Starting with his view that the astronomer should not depend on the natural philosopher, but also rejecting Ptolemy's view that an observational test was possible, Qūshjī made the remarkable claim that nothing false follows from the assumption of a rotating Earth. ${ }^{41}$

The connection with Copernicus, though, might seem tenuous at best. What makes this an arguable possibility is the remarkable coincidence between a passage in $D e$ revolutionibus (I.8) and one in Țūsî's Tadhkira (II.1[6]) in which Copernicus follows Ṭūsī's objection to Ptolemy's "proofs" of the Earth's immobility. ${ }^{42}$ This passage, which is quoted by numerous Islamic scholars after Țūsī, including Qūshjī, formed the starting point for their discussion of the Earth's possible motion. The closeness of the passage in Copernicus is one more bit of evidence that he seems to have been influenced not only by Islamic astronomical models but also by a conceptual revolution that was going on in Islamic astronomy. This conceptual revolution was opening up the possibility for an alternative "astronomical" physics that was independent of Aristotelian physics.

It is this point that has been missed up to now in seeking to understand the Islamic background to Copernicus. Clearly there is more to the Copernican revolution than some clever astronomical models that arose in the context of a criticism of Ptolemy. There also needed to be a new conceptualization of astronomy that could allow for an astronomically-based physics. But there is hardly anything like this in the European tradition before Copernicus. ${ }^{43}$ The fact that we can find a long, vigorous discussion in Islam of this issue intricately-tied to the question of the Earth's movement should indicate that such a conceptual foundation was there for the borrowing. It will be argued, of course, that the mechanism for such borrowing has yet to be found. But again, in my opinion it is more important at this point in our knowledge to focus on the products rather than the mechanism of transmission. By doing so, we can get a clearer idea not only of the possible Islamic connection to Copernicus but also of the Copernican revolution itself. 

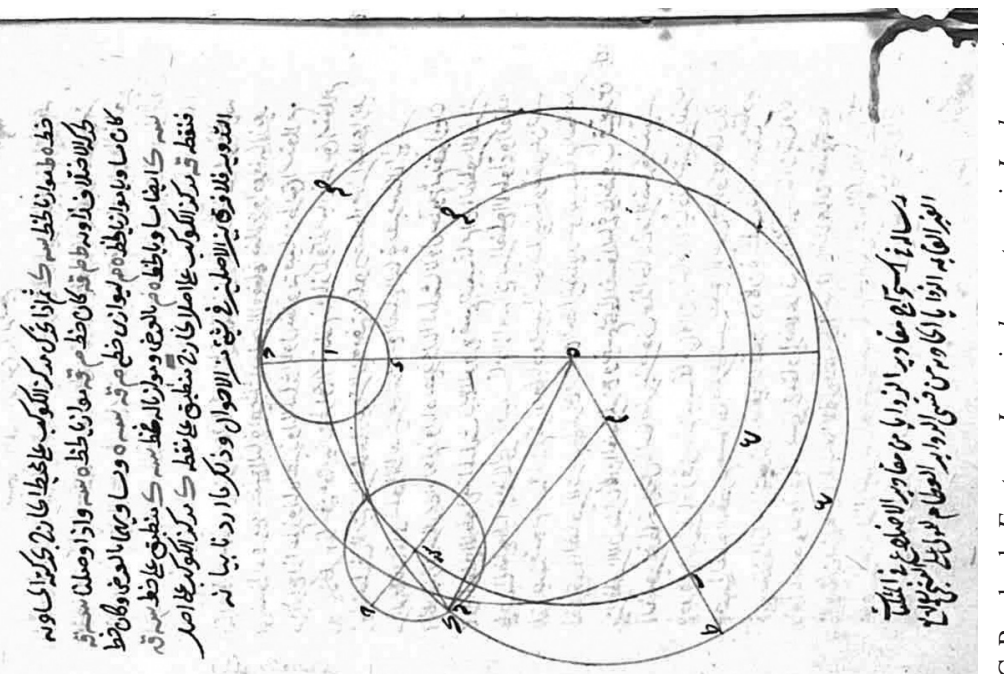

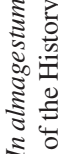

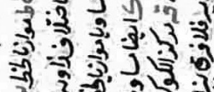

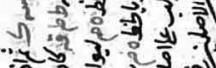
जै =ी जे उु जी 'के के की ). जी 1.7 जी जौ नी ई हैं $\Rightarrow$ ? $313=$ जी की जु र 3 की

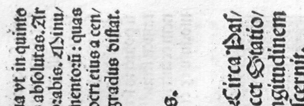

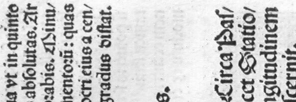
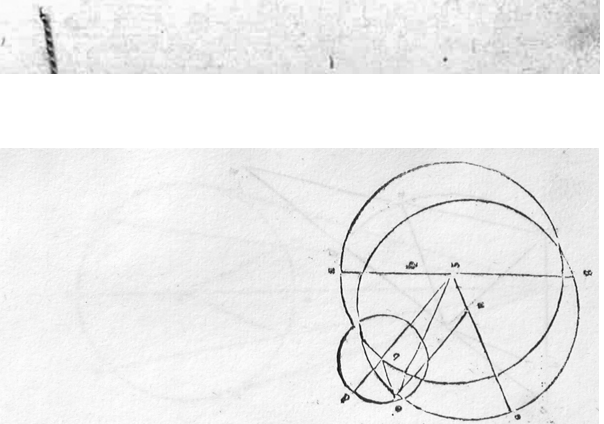

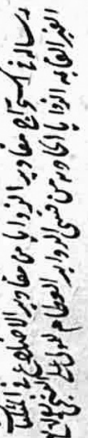

$\therefore$ 춘

$\stackrel{0}{0}$

¿ 8

ڤ

$\approx$

흉

ธิ 20

ฐ त्व

के

过世

ㅇํㅇㅠㅠ

记莡

ค. 을

ำ

를 己

药

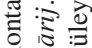

的

$\frac{0}{\frac{1}{2}} \stackrel{0}{\Xi}$

थ

旅

ชิ

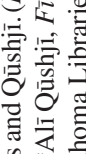

告芯

총 응

들 己 कू है क्ष ขै 등 เิ స్ํำ 50 ت. $\div$ 잉 ¿ 흘

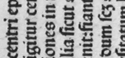

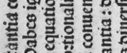
응

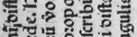
位位

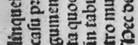
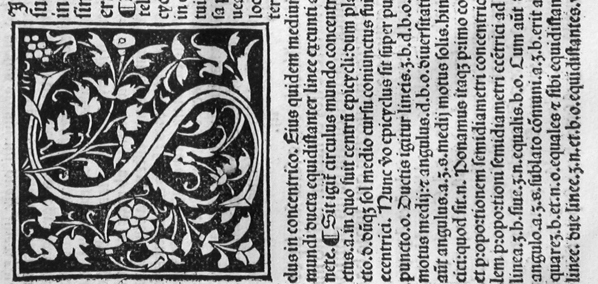

อิ 


\section{FURTHER THOUGHTS}

In the two years since I first developed the views expressed above, I have published a small treatise by ${ }^{\mathrm{c}} \mathrm{Alī}$ Qūshjī (d. 1474) that presents and proves a proposition that appears in Book XII of Regiomontanus's Epitome of the Almagest, which was completed in $1463 .{ }^{44}$ The importance of this proposition can scarcely be overstated, since it allows one to transform all of Ptolemy's planetary epicyclic models into eccentric models, which is generally accepted as crucial for the transformation from a geocentric to a heliocentric cosmology (see above). In that article, I argue that the possibility of a connection to Regiomontanus was strengthened by the lack of a context or justification in which Regiomontanus presented the proposition, which stands in stark contrast to the expansive manner in which Qūshjī discusses his own discovery (as a result of dealing with the Mercury model) and his attempt to explain why Ptolemy disallowed such a transformation for the lower planets (Mercury and Venus). The striking similarity of Qūshjī's figure that accompanies his text and that of Regiomontanus (Figure 1) adds to the possibility that this is a matter of transmission.

Given that Qūshjī was also willing to allow for the possibility of the Earth's rotation, the connections to Copernicus seem irresistible. Here I should emphasize the point that I made at the end of the original article above, namely that it is important to keep in mind that more is involved than a simple transmission of propositions or mathematical models. The sudden appearance in Europe at the end of the fifteenth century of what can be called "mathematical humanism" is what really demands an explanation. Obviously the interest in reforming and/or transforming the Ptolemaic system along the lines that had developed over many centuries in the hay'a tradition of eastern Islamic astronomy is one aspect of this. But clearly there is much more in Regiomontanus's mathematical Programme than Ptolemaic astronomy (although it plays a major role in his thinking). ${ }^{45}$ It is here that I think more work needs to be done.

James Stephen Byrne has recently argued that "Regiomontanus's vision of mathematics is that of a mathematician, rather than that of a historian, an educator, or a philosopher". Rather than viewing Regiomontanus simply through a humanist lens, Byrne contends that one should see his "mathematical humanism" as "deeply rooted in the traditional university curriculum ... [but] [a]bove all, it is rooted in mathematical texts, both curricular and extra-curricular". ${ }^{46}$ But as Michael Shank has pointed out: "With respect to the university, it is important to note first that from almost every point of view except intrinsic interest and later historiographical significance, the mathematical sciences at Vienna were on the margins. Institutionally, they had a place, but it was a minor one. They appear in the curriculum, but do not form its core. Statistically, they are distinctly in the minority; they are taught, read, and practiced by a minority." ${ }^{47}$ But Shank goes on to argue that this does not make them any less important or significant. And clearly there must have been some pre-existing interest in the mathematical sciences in order for Cardinal Bessarion, the Greek prelate who "desperately wanted to preserve and breathe new life into the intellectual heritage of classical Greece", to have inspired Peurbach and Regiomontanus to undertake what 
amounted to a resuscitation of the Ptolemaic astronomical tradition in Europe. ${ }^{48}$

If we accept Shank's position, and I believe we should, then we have moved at least part of the problem back to accounting for Bessarion's "mathematical humanism". This is a vexed question and raises the issue of the revival of interest in science during the Palaeologan period (1259-1453). It seems clear that Byzantine scholars were in contact with and were influenced by Islamic scientific developments. ${ }^{49}$ But how far did this influence extend? Since we have late Islamic models in Byzantine texts, and since we have other examples of Islamic texts in Byzantine form (the "Persian Tables", for example ${ }^{50}$ ), the transmission of scientific objects is obvious. But what of the less tangible, more conceptual aspects I have spoken of above? Is it possible to transmit ideas, in particular ideas about how to do science? I have argued elsewhere that this is indeed possible. ${ }^{51}$ Following on A. I. Sabra's notion of the "appropriation" of Greek science in Islam, I believe we can also speak of the transmission of a "moral economy" of science. (Here I borrow the terminology of L. J. Daston.) In this case, that transmission would have consisted of the notion that astronomy could, indeed should, be based upon a new set of physical principles that would be mathematically and empirically based, rather than upon Aristotelian natural philosophy. This, I contend, was also contained in the suitcase that Bessarion took with him to Vienna along with books and other objets de science.

Why do I not think this was not the result of the "predilections" of Peurbach and the young Regiomontanus, who somehow transmitted this to Copernicus in the next generation? For the same reason that I reject the parallelism argument. History takes time. In the Islamic world, the revolutionary rejection of Aristotelian physics in astronomy was something that took hundreds of years, dozens of scholars, and thousands of pages before it bore fruit in the person of ${ }^{\mathrm{c}} \mathrm{Al} \overline{\mathrm{i}} \mathrm{Qu}$ uhjī in Samarqand. The role of the physics of the Islamic theologians (mutakallims), the attack from various quarters on the Aristotelian claim of epistemic knowledge, the development of rhetorical tools to use in scientific argumentation, and the use of science to glorify God were all things that had counterparts in medieval Europe. What did not have a counterpart until the late fifteenth century was their interaction with the advanced astronomical tradition that had developed over many centuries within the Islamic world. In short, Regiomontanus, and his successors, reflect the mathematical humanism that had a brilliant but short life in Central Asia. ${ }^{52}$

In his stunning, but under-appreciated work on the origins of humanism in Islam, George Makdisi asks why we should bother about influence. His answer is that "by understanding where we came from in our intellectual culture we are apt to gain a better understanding of the civilization of the Christian West, not only that of classical Islam". And he concludes with poignancy and prescience: "What is certain is that the Western Christian and Classical Islamic civilizations have strongly interacted in the Middle Ages and in Modern Times, and will continue to interact far into the future." 53 


\section{ACKNOWLEDGEMENTS}

The first and largest part of this article (before "Further Thoughts") is a slightly revised version of the author's "Copernicus and his Islamic predecessors: Some historical remarks", which appeared in Filozofski vestnik, xxv (2004), 125-42. The author and Publisher are grateful to Dr Matjaž Vesel and Filozofski vestnik for permitting the reuse of this material. I also wish to thank Dr Nevzat Kaya (Istanbul) and Dr Marilyn Ogilvie (Oklahoma) for permission to reproduce images from their collections.

\section{REFERENCES}

1. These are: al-Battānī, al-Bițūjīi, al-Zarqāllu, Ibn Rushd, and Thābit ibn Qurra. Copernicus also refers to al-Battānī in his Commentariolus, which remained unpublished during his lifetime. "Islamic" here refers to the civilization of Islam, not the religion, since a number of "Islamic" astronomers, such as Thābit, were not Muslims.

2. J. L. E. Dreyer, History of the planetary systems from Thales to Kepler (Cambridge, 1906), 269. Dreyer knew of Țūsî̀s work from the translation by Carra de Vaux of a chapter of his al-Tadhkira fi cilm al-hay'a ("Les sphères célestes selon Nasīr Eddin-Attusî” in Paul Tannery, Recherches sur l'histoire de l'astronomie ancienne (Paris, 1893), Appendix VI, pp. 337-61).

3. These have been conveniently collected in E. S. Kennedy and Imad Ghanem (eds), The life \& work of Ibn al-Shātir: An Arab astronomer of the fourteenth century (Aleppo, 1976), and in E. S. Kennedy et al., Studies in the Islamic exact sciences (Beirut, 1983), 50-107. The most important of these is E. S. Kennedy, "Late medieval planetary theory", Isis, lvii (1966), 84-97.

4. See, for example, the very critical remarks, most likely by the Banū Mūsā (ninth century), in Régis Morelon, Thābit ibn Qurra: Euvres d'astronomie (Paris, 1987), 61.

5. F. J. Ragep, Nașīr al-Dīn al-Ṭūsì's memoir on astronomy (2 vols, New York, 1993), i, 48-51.

6. F. Jamil Ragep, "Ibn al-Haytham and Eudoxus: The revival of homocentric modeling in Islam", in Studies in the history of the exact sciences in honour of David Pingree, ed. by C. Burnett et al. (Leiden, 2004), 786-809.

7. George Saliba, "Ibn Sīnā and Abū cUbayd al-Jūzjānī: The problem of the Ptolemaic equant", Journal for the history of Arabic science, iv (1980), 376-403; reprinted in idem, A history of Arabic astronomy: Planetary theories during the golden age of Islam (New York, 1994), 85-112.

8. See Nūr al-Dīn abū Ishāq al-Bițūjīi, On the principles of astronomy, ed. and transl. by B. Goldstein (2 vols, New Haven, 1971). Cf. A. I. Sabra, "The Andalusian revolt against Ptolemaic astronomy: Averroes and al-Bițūjū̄", in Transformation and tradition in the sciences, ed. by E. Mendelsohn (Cambridge, 1984), 133-53.

9. Nicholas Copernicus, De revolutionibus orbium coelestium, transl. by E. Rosen as On the revolutions (Baltimore, 1978), 18.

10. Good overviews can be found in George Saliba, "The astronomical tradition of Maragha: A historical survey and prospects for future research", Arabic science and philosophy, i (1991), 67-99 (reprinted in idem, History (ref. 7), 258-90), and George Saliba, "Arabic planetary theories after the eleventh century AD", in Encyclopedia of the history of Arabic science, ed. by R. Rashed (3 vols, London, 1996), i, 58-127.

11. Today we would say that these mathematical tools were equivalent to linkages of constant-length vectors rotating at constant angular velocities; but it is important to remember that Islamic astronomers conceived of their devices as physical and not simply mathematical. $C f$. Ragep, op. cit. (ref. 5), ii, 433-7.

12. F. Jamil Ragep, "The two versions of the Ṭūsī couple", in From deferent to equant: Studies in honor 
of E. S. Kennedy, ed. by D. King and G. Saliba (The annals of the New York Academy of Sciences, d (1987)), 329-56.

13. N. M. Swerdlow and O. Neugebauer, Mathematical astronomy in Copernicus's De revolutionibus (2 parts, New York and Berlin, 1984), i, 47.

14. N. M. Swerdlow, "The derivation and first draft of Copernicus's planetary theory: A translation of the Commentariolus with commentary", Proceedings of the American Philosophical Society, cxvii (1973), 423-512, p. 434.

15. Admittedly, this is a grossly simplified version of a fuller and much more careful exposition that one may find in Swerdlow and Neugebauer, op. cit. (ref. 13), i, 41-64. A good summary is also provided by Michael H. Shank, "Regiomontanus on Ptolemy, physical orbs, and astronomical fictionalism: Goldsteinian themes in the 'Defense of Theon against George of Trebizond"', Perspectives on science: Historical, philosophical, social, x (2002), 179-207.

16. Swerdlow and Neugebauer, op. cit. (ref. 13), i, 47. Cf. Neugebauer's earlier remark that "The mathematical logic of these methods is such that the purely historical problem of contact or transmission, as opposed to independent discovery, becomes a rather minor one" (O. Neugebauer, "On the planetary theory of Copernicus", in Vistas in astronomy, x (1968), 89-103, p. 90; reprinted in idem, Astronomy and history (New York, 1983), 491-505, p. 492).

17. N. Swerdlow, "Copernicus, Nicolaus (1473-1543)", in Encyclopedia of the scientific revolution from Copernicus to Newton, ed. by W. Applebaum (New York and London, 2000), 165.

18. Swerdlow and Neugebauer claim that it is a translation. The recent editors and translators of the text argue that it is an original Byzantine work that is simply influenced to some degree by Arabic or Persian sources (E. A. Paschos and P. Sotiroudis, The schemata of the stars (Singapore, 1998), 11-18). The closeness to Islamic sources, however, and the use of the standard Arabic corruption Kakkaous rather than the Greek Cepheus argue for a greater dependence than the authors wish to admit. Clearly more research on this question is needed.

19. See N. Swerdlow, "Aristotelian planetary theory in the Renaissance: Giovanni Battista Amico's homocentric spheres", Journal for the history of astronomy, iii (1972), 36-48, and Mario Di Bono, "Copernicus, Amico, Fracastoro and Țūsī's device: Observations on the use and transmission of a model", Journal for the history of astronomy, xxvi (1995), 133-54. In a passage in III.4 of De revolutionibus that was deleted prior to publication, Copernicus himself speaks of others who had used the Țūsī device; see Ragep, op. cit. (ref. 5), ii, 431.

20. Willy Hartner, "Copernicus, the man, the work, and its history", Proceedings of the American Philosophical Society, cxvii (1973), 413-22, p. 421.

21. A session at a recent American History of Science Society annual meeting was entitled: "The late, great scientific revolution". Cf. Margaret J. Osler (ed.), Rethinking the scientific revolution (Cambridge, 2000).

22. Two recent examples are Peter Dear's Revolutionizing the sciences: European knowledge and its ambitions, 1500-1700 (Princeton, 2001), and Steven Shapin's The scientific revolution (Chicago, 1996). Both ignore Islamic science entirely and scarcely discuss medieval European contributions to the scientific revolution.

23. Copernicus's conservatism was emphasized in 1959 both in a scholarly and in a popular context. As for the former, Derek de Solla Price's "Contra-Copernicus" provided a technical account that showed that Copernicus was really still part of ancient and medieval astronomy. As Price concludes: “... Copernicus made a fortunate philosophical guess without any observation to prove or disprove his ideas, and ... his work as a mathematical astronomer was uninspired. From this point of view his book is conservative and a mere reshuffled version of the Almagest" (Derek J. de S. Price, "Contra-Copernicus: A critical re-estimation of the mathematical planetary theory of Ptolemy, Copernicus, and Kepler", in Critical problems in the history of science, ed. by M. Clagett (Madison, 1969), 197-218, p. 216). The popular presentation of this viewpoint was made 
by Arthur Koestler in his The sleep walkers: A history of man's changing vision of the universe (London, 1959), where Copernicus is referred to as the "timid canon". How Copernicus can be "saved" despite this conservatism and/or his connection to Islamic astronomy is well-illustrated by Erna Hilfstein's remarks regarding the significance of Copernicus's achievement: "Copernicus may have used the geometrical devices of his Greek or Arab predecessors (for example, from the 'Maragha school'), yet his system, and the perception of the cosmos it established, was entirely novel" ("Introduction to the softcover edition" of Nicholas Copernicus, On the revolutions, transl. and comm. by E. Rosen (Baltimore, 1992), p. xiii.

24. We should note, though, that recently Michał Kokowski, in defending Copernicus's originality, has also conceded that the Islamic models are also somehow revolutionary according to his "correspondence principle" inasmuch as they supersede those of Ptolemy by overcoming the problematic equant (Copernicus's originality: Towards integration of contemporary Copernican studies (Warsaw, 2004), 75-77). Here he follows George Saliba, who maintained that the Marāgha school astronomers were revolutionary because of their "realization that astronomy ought to describe the behaviour of physical bodies in mathematical language, and should not remain a mathematical hypothesis, which would only save the phenomena" ("The rôle of Maragha in the development of Islamic astronomy: A scientific revolution before the Renaissance", Revue de synthèse, cviii (1987), 361-73, p. 372; reprinted in idem, History (ref. 7), 245-57, p. 256). It is not clear how Saliba reconciles this position with his later claim that the sixteenth-century astronomer al-Khafrī had reached "unparalleled heights" in this tradition by "realiz[ing] that all mathematical modeling had no physical truth by itself and was simply another language with which one could describe the physical observed reality" (George Saliba, "Arabic versus Greek astronomy: A debate over the foundations of science", Perspectives on science, viii (2000), $328-41$, p. 339). For a contrary view, see A. I. Sabra, who has argued that this Islamic scientific tradition was not revolutionary but should be regarded as "normal science" in the Kuhnian sense ("Configuring the universe: Aporetic, problem solving, and kinematic modeling as themes of Arabic astronomy”, Perspectives on science, vi (1998), 288-330, pp. 292, 321-3). As should be clear in what follows, I believe that the emphasis on the mathematical models - whether revolutionary or not - has distracted us from what is the most significant and innovative part of Islamic theoretical astronomy.

25. Recent books by two mediaevalists, A. C. Crombie and Edward Grant, advocate the European nature of modern science, thus reverting to the more traditional viewpoint. See Crombie's Styles of scientific thinking in the European tradition: The history of argument and explanation especially in the mathematical and biomedical sciences and arts (London, 1994), and Grant's The foundations of modern science in the Middle Ages: Their religious, institutional, and intellectual contexts (Cambridge, 1996) and idem, God and reason in the Middle Ages (Cambridge, 2001). This view is held by both Western and Islamic scholars so cannot be simply ascribed to some biased antagonism towards Islamic civilization. For example, the Iranian expatriate S. H. Nasr has stated that although "all that is astronomically new in Copernicus can be found essentially in the school of al-Ṭūsî”, Islamic astronomers were prescient enough not to break with the traditional Ptolemaic cosmology "because that would have meant not only a revolution in astronomy, but also an upheaval in the religious, philosophical and social domains" (S. H. Nasr, Science and civilization in Islam, 2nd edn (Cambridge, 1987), 174).

26. $C f$. Sonja Brentjes, "Between doubts and certainties: On the place of history of science in Islamic societies within the field of history of science", N.T.M., xi (2003), 65-79.

27. J. Dobrzycki and R. L. Kremer, "Peurbach and Marāgha astronomy? The ephemerides of Johannes Angelus and their implications", Journal for the history of astronomy, xxvii (1996), 187-237, p. 211.

28. I. N. Veselovsky, "Copernicus and Nașīr al-Dīn al-Țūsī”, Journal for the history of astronomy, iv (1973), 128-30. This turns out to be implausible since Copernicus probably did not know of the 
Proclus theorem (actually the converse of the Țūsī couple) until many years after he used the device; see Ragep, op. cit. (ref. 5), ii, 430-1.

29. Di Bono, op. cit. (ref. 19), 153-4.

30. Swerdlow, op. cit. (ref. 14), 434-5.

31. Recently B. R. Goldstein ("Copernicus and the origin of his heliocentric system", Journal for the history of astronomy, xxxiii (2002), 219-35) has sought to undermine Swerdlow's reconstruction of the origins of Copernicus's heliocentric system by emphasizing a passage in De revolutionibus (I.10). In it Copernicus points to the distance-period relationship of the planets to justify his system, which Goldstein takes to be the initial motivation. But again, it is odd that this is hardly mentioned in the Commentariolus.

32. For this Spanish episode in Islamic astronomy, see Sabra, op. cit. (ref. 8), 133-53.

33. It is difficult, if not impossible, to prove a negative, but it is highly suggestive that one does not find the word "equant" in Edward Grant's monumental (816-page) Planets, stars, and orbs: The medieval cosmos, 1200-1687 (Cambridge, 1994). Even in the generation immediately before Copernicus, there seems to have been no precedent for what was a commonplace in Islamic astronomy. As stated in Dobrzycki and Kremer, op. cit. (ref. 27), 211: "We know of no extant text by Peurbach or Regiomontanus in which the Ptolemaic models are criticized explicitly on the grounds that they violate uniform, circular motion."

34. G. J. Toomer, Ptolemy's Almagest (London, 1984), 36.

35. The translation is due to T. L. Heath in his Aristarchus of Samos (Oxford, 1913), 276; reprinted in Morris R. Cohen and I. E. Drabkin, A source book in Greek science (Cambridge MA, 1948), 90-91. Cf. G. E. R. Lloyd, "Saving the appearances", Classical quarterly, n.s., xxviii (1978), 202-22, pp. 212-14 (reprinted with new introduction in idem, Methods and problems in Greek science (Cambridge, 1991), 248-77).

36. Ragep, op. cit. (ref. 5), i, 38-41, 106-7; ii, 386-8.

37. Much of what follows is elaborated in F. Jamil Ragep, "Freeing astronomy from philosophy: An aspect of Islamic influence on science", Osiris, xvi (2001), 49-71.

38. Ragep, op. cit. (ref. 5), i, 44-46, 98-101; ii, 380-1.

39. Ragep, op. cit. (ref. 37), 61-63.

40. A discussion of this Islamic discourse on the Earth's possible rotation is in F. Jamil Ragep, "Ṭūsī and Copernicus: The Earth's motion in context", Science in context, xiv (2001), 145-63.

41. Ibid., 157.

42. Ibid., 145-8.

43. In the fourteenth century, one finds Nicole Oresme and Jean Buridan discussing the Earth's rotation. The former, in particular, presents quite cogent reasons why one might believe in this motion. But in the end he rejects them for theological reasons. In both cases, it is clear that they have no interest in a reconceptualization of astronomy along the lines that occurred in Islamic astronomy (ibid., 158-60). The possibility that such a discussion might have taken place in the fifteenth century in the circle of Peurbach and Regiomontanus is being investigated by M. Shank; $c f$. op. cit. (ref. 15).

44. F. Jamil Ragep, "A Ali Qūshjī and Regiomontanus: Eccentric transformations and Copernican revolutions", Journal for the history of astronomy, xxxvi (2005), 359-71.

45. See Menso Folkerts, "Regiomontanus' role in the transmission and transformation of Greek mathematics", in Tradition, transmission, transformation: Proceedings of two conferences on premodern science held at the University of Oklahoma, ed. by F. J. Ragep and S. P. Ragep (Leiden, 1996), 89-113.

46. James Steven Byrne, "A humanist history of mathematics? Regiomontanus's Padua Oration in context", Journal of the history of ideas, 1xvii (2006), 41-61, p. 61. 
47. Michael H. Shank, "The classical scientific tradition in fifteenth-century Vienna”, in F. J. Ragep and S. P. Ragep (eds), Tradition, transmission, transformation (ref. 45), 115-36, p. 131.

48. Ibid., 126.

49. See above, ref. 18 (on the transmission of Islamic astronomy to Byzantium). And as Otto Neugebauer has remarked: "There is no reason to assume that there is any period in which Islamic astronomy was not known in Constantinople" (A history of ancient mathematical astronomy (3 parts, New York, 1975), i, 11). Cf. Maria Mavroudi, A Byzantine book on dream interpretation: The Oneirocriticon of Achmet and its Arabic sources (Leiden, 2002); Alain Touwaide, "Arabic urology in Byzantium", Journal of nephrology, xvii (2004), 583-9; and Alain Touwaide, "Arabic medicine in Greek translation: A preliminary report", Journal of the International Society for the History of Islamic Medicine, i (2002), 45-53.

50. Anne Tihon, "Les tables astronomiques persane à Constantinople dans la première moitié du XIVe siècle", Byzantion, lvii (1987), 471-87. Reprinted in Tihon, Études d'astronomie Byzantine (Aldershot, 1994).

51. F. J. Ragep and S. P. Ragep (eds), Tradition, transmission, transformation (ref. 45), pp. xv-xviii.

52. A very important article that takes up the mathematical humanism of Samarqand is İhsan Fazlıoglu's "Osmanlı felsefe-biliminin arkaplanı: Semerkand matematik-astronomi okulu", Dîvân ilmî araştırmalar, xiv/1 (2003), 1-66. A revised version in English will appear in a forthcoming issue of the Journal for the history of Arabic science.

53. George Makdisi, The rise of humanism in classical Islam and the Christian West (Edinburgh, 1990), $349-50$, p. 354. 